\title{
The Scope of Statutory Protection on the Use of Identical or Confusingly Similar Names by Businesses in Bangladesh
}

\author{
Dr. Shima Zaman*
}

\section{Introduction}

The concomitant purpose of protection of consumers from various misleading or unfair practices and the protection of goodwill of businesses are among the cardinal objectives of corporate law. There is no doubt that exactly identical name between two commercial entities would confuse consumers. However, the law goes beyond this and frowns upon names which may not necessarily be identical, but confusingly similar and may thus, encroach on the goodwill of a business and also mislead the customers. ${ }^{1}$ Thus, the reach of the legal restriction transcends beyond outright identical names and also applies to names which may cause deception of confusion. Otherwise, it would not only be deceit on consumers, but many unscrupulous would be able to unfairly profit by piggybacking on the reputation built by other businesses. Statutes on commercial law does this. In keeping with this trend, Section 11 of the Companies Act 1994 does the same (as did its predecessor Companies Act 1913) seeks to do this in the case of company names. This Section proscribes the use of an identical or deceptively similar name by two companies. This article would conduct an in-depth analysis of this Section and other relevant statutory provisions dealing with company names. It would also thoroughly analyse a decision of the Appellate Division of the Supreme Court (AD) in Shafquat Haider \& Ors v M. Al-Amin \& Ano. ${ }^{2}$

Shafquat Haider case presents a good case study on the problem that may sometimes arise with businesses operating on identical or confusingly similar names. If both of those entities in question happens to be incorporated business, Section 11 of the Companies Act 1913 or Companies Act 1994 may provide ample remedies against any unfair use of the name of a company by another one. However, this article will demonstrate that Section 11 is only applicable to incorporated entities and also there is no specific law in Bangladesh offering protection against unfair

\footnotetext{
Professor, Department of Law, University of Dhaka.
}

For a comprehensive analysis of company name related disputes in other jurisdictions, see JB Cilliers, 'Similar Company Names: A Comparative Analysis and Suggested Approach - Part 2' (1999) 62 Tydskrif vir Hedendaagse Romeins-Hollandse Reg (Journal for Contemporary RomanDutch Law) 57; JB Cilliers, 'Similar Company Names: A Comparative Analysis and Suggested Approach - Part 1' (1998) 61 Tydskrif vir Hedendaagse Romeins-Hollandse Reg (Journal for Contemporary Roman-Dutch Law) 582; Thomas G. P. Guilbert, 'Corporate Names and Assumed Business Names: Deceptively Similar Creates a Likelihood of Confusion' (1983) 62 Orlando Law Review 151.

2199111 BLD (HCD) 284, on appeal (1987) 7 BLD (AD) 130 [Shafquat Haider v M. Al-Amin]. 
competition per se. ${ }^{3}$ Thus, potentially an action for passing off would seem to be the only viable remedy for affected business be that incorporated or unincorporated. However, this article would demonstrate that an action for passing off may not always offer ample protection. Hence, it recommends that there be some changes made in the Companies Act 1994 along the lines of the relevant provisions in the Companies Act 2006 of the United Kingdom and Companies Act 2013 of India which may prove to be useful in giving adequate remedies to businesses.

The following parts of this article discuss the value of a company name and the rationale behind the protection of a company's name, the relevant provisions of the statute in force in Bangladesh. It also thoroughly analyses the relevant decision of the $\mathrm{AD}$, and also examines some other relevant reported cases of home and abroad. It argues that while business operating for many others may be easily protected from the unscrupulous or deceitful appropriation of its name by other businesses, the relatively new entrants to the market may find it difficult to get a suitable remedy. More importantly, a statutory remedy may offer more clarity and certainty than that of action for passing off, a common law-based remedy. Furthermore, a statutory remedy which is enforceable by presenting an application to the Registrar of Joint Stock Companies (RJSC) may also be prompter and less costly. The readers of this article should note that a company's name may also give rise to issue with conflicting domain names, but that issue is beyond the scope of the paper. ${ }^{4}$

\section{The Importance of and Rationale for Protection of Business Names}

While the observation that "to the person going into business, name selection is usually dealt with after most of the other aspects of the enterprise have been considered and acted upon to a substantial extent" the choice of name for companies is by no means a peripheral task as it may have perennial legal as well as commercial consequences. Without a name, a company cannot be incorporated as a corporate actor. The business reality of the contemporary world makes the name of a company something so important that every business would vigorously seek to protect it. Naturally, just like human beings are known by their names, the name is essential to the very existence of a company; it is one of the

3 While there is the Consumer Rights Protection Act 2009, the scope of that legislation is rather narrow and it only applies to some sort of small-scale remedies offered to consumers affected by legal infractions of businesses. The various remedies a business may need against any practice by its competitors is not covered by this law. For a scholarly analysis of the Act, See Dr. Shima Zaman, 'Revisiting the Consumer Rights Protection Act, 2009' (2016) 27(2) Dhaka University Law Journal 1.

4 See, Alan I. Cyrlin, 'Reducing a Company's Risk over Domain Name Disputes' (1999) 81 Journal of the Patent and Trademark Office Society 42; See also, Adam Chase, 'A Primer on Recent Domain Name Disputes' (1998) 3 Virginia Journal of Law \& Technology 1; See more Neal J. Friedman \& Kevin Siebert, 'The Name Is Not Always the Same' (1997) 20 Seattle University Law Review 631.

5 John W. Ennis, 'Some Problems in Choosing a Commercial Name' (1954) 28 Temple Law Quarterly 123. 
indispensable attributes of a company, and is the very way of identification. ${ }^{6}$ Indeed, it is by its name that the company would seek to protect its legal identity notwithstanding the persistent changes in its membership, its charter, and various array of commercial activities. ${ }^{7}$ Or perhaps, more appropriately, as pointed by a scholar that the name may be more important for a company than a natural person in that "[i]individuals may be identified by their physical peculiarities, but a corporation, which has been said to be 'intangible, invisible, and existing only in contemplation of law' is identified by its name."

Just as human beings may fondly cherish interactions with other human beings, the same may also to some extent, apply to interactions with juristic entities such as companies. Even a casual customer may recall a fair deal received from a company and may remember the corporate name in case occasion again arises for purchasing the goods or services or patronising that same company in future occasions. ${ }^{9}$ Thus, for a company the necessity for preserving and continuing to operate under one name may be like that of an individual who is persistently meeting new people who would know that individual by her/his name the consistency of which is important. ${ }^{10}$ The prudent promoters of a company would naturally invest effort in choosing a name that will be able to attract the attention and that the consuming public will be able to remember it. ${ }^{11}$ Indeed, it may be fairly said that by protecting the registered name of a company, the law in effect grants it a de facto monopoly of conducting corporate activity under the name so registered. ${ }^{12}$

Increased industrial and commercial activities coupled with technological advancement have resulted in an increase in the number of incorporated entities and have raised questions relating to the name of companies not raised hitherto. ${ }^{13}$ Significant investment in advertising has made the stakes in the company name even higher, as has already been pointed out here that it is a crucial marketing factor in

Cilliers ( n 1) 582-583.

ibid.

B. A. Whitney, 'The Corporate Name' (1930) 2 Corporate Practice Review 43.

ibid 44.

ibid.

11 Lucian W. Beavers \& William R. Laney, 'Choosing and Protecting the Corporate Name' (1977) 30 Oklahoma Law Review 507.

12 See also Hambidge, 'A Tale of Two Names: The Protection of a Company Name with Specific Reference to the Companies Amendment Act 18 of 1990' (1990) 2 South African Mercantile Law Journal 333.

13 Cilliers (n 1). However, it would be rather simplistic to assume that the concern of the protection of businesses from the deceptive use of names is only a contemporary concern. While modern technologies and importance of advertisement may have made the stakes higher, it would seem that businesses for a very long period of time clearly realised the value of protecting their names because of its close association with goodwill. For early expositions of this matter, see for example, W. W Putnam, 'Unfair Competition by the Deceptive Use of One's Own Name'(1898-1899) 12 Harvard Law Review 243; 'Corporations - Right to Corporate Name' (1908) Canadian Law Times, 28(8) 641. 
gaining familiarity among prospective customers. ${ }^{14}$ The name of a company is not only a matter of distinctiveness and legality but also of appealing to customers or performance in search engines etc. A study has even concluded that companies with names that are easier to pronounce may outdo companies with difficult to- pronounce names in the early days of trading. ${ }^{15}$ The name of a company may also be directly linked with its profit as it may be associated with its performance in internet search engines. This has given rise to a practice that companies may seek particularly imaginative names to increase the likelihood that their sites will top the search results. ${ }^{16}$ Given the use of online search engines in the day to day urban life of people in advanced economies such an investment would be clearly rational therein, and it may also be so in an economically developing country like Bangladesh. ${ }^{17}$

More often than not a successful business enterprise would acquire so much commercial goodwill ${ }^{18}$ in respect of its products or services that members of the public and consumers would associate with the company name so that a company name has become a more and more valuable asset in itself. ${ }^{19}$ Any laxity in choosing an appropriate name for a company may bring about catastrophic results for the company it as its chosen name may then infringe someone else's trade name or mark. ${ }^{20}$ After investing much time and money in establishing the goodwill and notoriety of the chosen name, the company may be required to abandon the name that

14 ibid. See also, Laura A. Heymann, 'A Name I Call Myself: Creativity and Naming' (2012) 2 University of California Irvine Law Review 585, 594, citing James Gleick, 'Get Out of My Namespace' (New York Times, 21 March 2004) § 6, at 44 noting that often pharmaceutical companies would spend millions on market research to make sure that their names become appealing.

15 ibid, Heymann, citing Adam L. Alter \& Daniel M. Oppenheimer, Predicting Short-Term Stock Fluctuations by Using Processing Fluency, (2006) 103 Proceedings of National Academy of Sciences 9369, 9371.

ibid, citing Seth Godin, 'The New Rules of Naming' (Seth Godin's Blog, 16 October 2005) < https://seths.blog/2005/10/the_new_rules_o/ > accessed 20 November 2020.

17

As per the data of Bangladesh Telecommunication Regulatory Commission, the telecommunications regulator in Bangladesh, as of June 20202, there were more than 100 million internet subscribers in Bangladesh, see 'Number of Internet Users Crosses 103 Million in Bangladesh' The Financial Express (Online, 7 August 2020) <https://thefinancialexpress.com.bd/trade/number-of-internetusers-crosses-103-million-in-bangladesh-1596786757> accessed 16 October 2020. Thus, it would seem that at least more than half of the population have an active internet connection. This number of people with internet access, concomitant with a tendency of online shopping, it is possible that online presence would be a critical factor for many businesses in Bangladesh in the near future, if it already has not become so. However, a caveat has to be that the number of internet subscriptions in and of itself does not offer an unequivocal picture about the time spent on the internet, let alone any usage of such internet connections for accessing goods and services offered by businesses.

18 Lord MacNaghten in The Commissioners of Inland Revenue v Muller \& Co's Margerine Ltd [1901] 1 AC 217, 223-224, has defined goodwill eloquently in the following words: "It is a thing very easy to describe, very difficult to define. It is the benefit and advantage of a good name, reputation, and connection of a business ... It is the one thing which distinguishes an old established business from a new business at its first start." ibid.

20 Beavers \& Laney (n 11). 
it has already chosen, advertised, and functioned upon. ${ }^{21}$ While there seems to be no precedent for this in Bangladesh, in other jurisdictions, not just the company itself, but also corporate officers have been liable in damages as joint tort feasors in the violation of the trademark rights of others by choosing names impinging on the property right of the plaintiffs. ${ }^{22}$ Thus, it is incumbent on the promoters to resort to due diligence in choosing an appropriate name for their proposed company.

\section{The Statutory Provisions on Company and Partnership Names}

Before moving on to discuss the facts of the case or analyse the decision of the $\mathrm{AD}$, it may be useful to analyse the relevant provision of the Companies Act 1913 and its successor, the Companies Act 1994. Section 11 of both of these laws deal with name of companies. Section 11(1) of the Companies Act 1913 provided (as does the Companies Act 1994) that a company would not be registered by a name identical with that by which a company in existence is already registered, or so nearly resembling the name that there is a likelihood of using the name to deceive, unless the company in existence is in the course of being dissolved and it signifies its written consent to such use.

Section 11(2) provided that if a company, through inadvertence or otherwise, is, without the consent as referred to in sub-section (1), gets registered by a name identical with that by which a company in existence is previously registered, or so nearly resembling the name that there is a likelihood of using the name to deceive, the first mentioned company would, on the direction of the Registrar, change its name within a period of one hundred and twenty days. Under the current law, if it does not do so, the company and its responsible officials would be liable to pay a fine. ${ }^{23}$ However, under the Companies Act 1913, no corresponding provision existed. It is important to note here that the onus is on the applicant for the registration of a new company, i.e., the promoters to ensure that the name for their proposed company does not match with the name of any existing company. Under the current Companies statute in force, upon the payment of a nominal fee, the Office of the RJSC provides a name searching service as is required by Section 11(9). The provision requires that the RJSC would advise the applicant within a month of the application. However, it would appear from the wording used in the Section that such a search by the RJSC would only be limited to the similarity with the name of companies already registered. The search would have nothing to do with any similarity of name with other forms of businesses nor any trade mark associated with an incorporated or unincorporated entity.

\footnotetext{
ibid.

2 ibid.

23 Companies Act 1994 (Bangladesh), s 11(3). Section 11 of the Companies Act 1913 did not have any corresponding provision.
} 
Furthermore, Section 11(5) of the Companies Act 1994 stipulates that no company would be registered by a name containing in any form the name or any abbreviation of the name of the United Nations or of any subsidiary body set up by the UN or of the World Health Organisation unless the company has obtained the previous written authorisation of the Secretary General or Director General of the respective organisation. Apart from the Companies Act 1994, Sections 3 to 7 of the Bangladesh Names and Emblems (Prevention of Unauthorised Use) Order 1972 also enshrines certain restriction on company names that may deceive consumers. In particular, Section 3(1) provides that none authority would register a company or firm or other body of persons which bears a name, or any abbreviation of a name which are specified in the Schedule. ${ }^{24}$ The focus of this law is the protection of the public from deception than the protection of goodwill of any particular business entity. Restrictions along the line of this latter set of provisions designed to protect public and the misleading use of the Government, Bangabandhu, and UN, WHO, and other international organizations also exist in Sections 58(3), 58(3)A, 58(3)B of the Partnership Act $1932{ }^{25}$

\section{The Facts of the Case}

Mr. M. Al-Amin and his mother, Dr. Jahan Ara Begum, were owners of fifty percent shares and are two, out of four Directors of Ciproco Computers Limited, which was registered in June 1985. They filed an application for winding up of the Company essentially claiming that there is a deadlock in the Company arising from the difference of opinion among the two competing groups of shareholders each holding 50 per cent shares in the Company. ${ }^{26} \mathrm{Mr}$. Sahfquat Haider, and his wife, the opposite parties, were also owners of fifty per cent shares in the Company, and the remaining two directors of the Company, were. Mr. Al-Amin was the chairperson of the board of directors and Mr. Haider was the managing director. The Company was engaged in import, sale and servicing of computer machines of various kinds which were manufactured by reputed foreign businesses. ${ }^{27}$ For some time following the incorporation, the Company was doing business in computer machinery smoothly, but then the relationship between the petitioners and the opposite parties crumbled. ${ }^{28}$ Hence, Mr. Al. Amin and his mother, filed an application under Section 162 of the

24 The schedule includes the Bangladesh flag; official seal, insignia or coat-of-arms of the Government of the People's Republic of Bangladesh; or official seal, insignia or coat-of-arms of the any Ministry of the Government of the People's Republic of Bangladesh; the name, title or semblance or any variation of Bangabandhu; or the name of a foreign state.

28 ibid. 
Companies Act 1913 for winding up of the company alleging deadlock in its affairs due to the dispute between the two factions of the directors. ${ }^{29}$

Following the winding up petition, the opposite parties in the winding up proceeding and appellants in the case before the $\mathrm{AD}$ filed an application for temporary injunction praying that the respondents be restrained from carrying on a business in the name of Ciproco Computers. ${ }^{30}$ They alleged that the respondents even requested Company's customers to cancel their existing orders with the Company and issue new orders to Ciproco Computers as opposed to Ciproco Computers Ltd as they pretended the former was going to take the place of the latter. ${ }^{31}$ They claimed that as the winding up petition was pending before the HCD, such a practice was an unfair effort to entice away the customers of the Company to his personal business at the detriment of the company. ${ }^{32}$

The respondents claimed that the Ciproco Computers was actually in existence since 1981, well before the Ciproco Computers Ltd was incorporated and started its operation well ahead of the Ciproco Computers Ltd. ${ }^{33} \mathrm{Mr}$. Al Amin, the respondent no.1 claimed that he was the promoter of Ciproco Computers Ltd and he invited Mr. Shafqat Haider as to join the Company and made him the managing director. He also showed that he had a trade mark registration in January 1984 under the Trade Marks Act 1940 with the words 'Ciproco Computers' in favour of his separate private business. ${ }^{34}$ Respondent no. 1, Mr. Al-Amin contented that he revealed in a board meeting of Ciproco Computers Ltd. that he would resume his personal business and the trade license was a mere formality as already was the proprietor of the registered trade mark 'Ciproco'. 35

However, the AD noted that there was evidence of the activities of the business of the respondent between 1981 and 1983. However, there was no evidence presented to it indicating that respondent no. 1 carried on his personal business, that is Ciproco

29 It may be pertinent to mentioned that the High Court Division of the Supreme Court ultimately rejected the winding up petition alleging that the application of the petitioner was not justified, see M. Al Amin and another v Shafquat Haider and another (1991) 11 BLD (HCD) 284. However, it may be argued that in view of the deadlock between the two factions of shareholders and directors, winding up could potentially have been a remedy in the case. For instance, in Bengal Waterways Ltd. $v$ Rahimuddin Ahmed, (1982) 34 DLR (AD) 47, it was decided by the Appellate Division that although deadlock in the affairs of the company is not mentioned as a ground for winding up of a company, the Court may do so if it deems that such an order would be just and equitable. The Court [at para 22, also observed that "it is a well-settled principle that a private limited company can, if circumstances so permit, be wound up on the principle of dissolution of partnership firm."

Shafquat Haider v M. Al-Amin (n 2), para 3.

ibid.

ibid.

ibid, para 4.

ibid.

ibid. 
Computers after the incorporation of the Company. ${ }^{36}$ In other words, in the period intervening the incorporation of Ciproco Computers Ltd and the disagreement between the two factions, no evidence of business activity of the business 'Ciproco Computers' was presented to the Court. Thus, the Court found that Ciproco Computers was trying to unfairly gain from the goodwill of Ciproco Computers Ltd. This was all the more evident to the $\mathrm{AD}$ from the fact that Ciproco Computers obtained trade license only on 28 May 1986, only around two weeks before the commencement of the winding up proceedings. The Court discussed a number of Indian and English cases and observed that when there were similarities between the name of companies, courts have in some cases ordered injunction, and in some others, the courts have refused to do so. ${ }^{37}$ The Court observed that the demarcation line in those cases was "whether the similarity of name or mark was such as to create confusion or deceive the public." 38 And applying that test, the AD had no difficulty in arriving at the conclusion that there was not only a similarity in the name of the two enterprises but also a strong likelihood of confusion among the consumers. ${ }^{39}$

The AD also rightly found that the action of the respondent, was, in fact, deceptive. Therefore, the AD upheld the application for injunction and ordered that respondent No. 1 to restrain from using the trade name "Ciproco Computers" till the High Court Division (HCD) decides the winding up petition. But the AD refrained from passing any order on respondent No. 1 performing his duties as the Chairperson of Ciproco Computers Ltd possibly because that was more to do with the winding up proceedings pending before the HCD and had no direct bearing in the case at hand where the core issue was the promotion of his personal business at the expense of the Company.

\section{Analysis of the Decision of the Appellate Division and the Scope for Amending the Companies Act}

Based on the decision of the $\mathrm{AD}$ in this case, it may be said that the statutory restraint on using an identical or confusingly similar name as provided for in Section 11 of the Companies Act may not only always be limited to other incorporated entities but in appropriate cases may well be also applicable to unincorporated business entities particularly when there is a deceptive practice by someone. At least, in this case, the Court though referred to Section 11 of the Companies Act 1913 it clearly did not find itself to be constrained by the express wordings in the Section. Indeed, Section 11 of neither the Companies Act 1913 nor the Companies Act 1994 says anything about the similarity of names between corporate and unincorporated entities. It is interesting to

\footnotetext{
ibid, para 5 .

ibid, paras 6-9.

ibid, para 10.

ibid.
} 
note that the HCD took a very narrow and literal view of the matter. ${ }^{40}$ Obviously, due to the distinct characteristics of a partnership and a company, the finding of the HCD is legally tenable. It is well-known that when a sole ownership business or a partnership business is transformed into a body corporate, its legal character (if not always the factual character) completely changes. ${ }^{41}$

However, it would be respectfully submitted that the HCD's technical reading has ignored the commercial reality. The HCD could, and it would be argued here should have considered the reality of the relevant market. Had the relevant market i.e. the market of computer and its accessories were limited to persons with expertise in law and/ commerce, the technical legal difference between a corporate and unincorporated business would have been apparent to customers which would have dispelled any potential confusion (even though the unfairness of a party to the Company doing personal business in competition with that of the Company could arguably be an issue). ${ }^{42}$ It is dubious that few if at all any of the customers of Ciproco Computers would have noticed let alone appreciated the difference between Ciproco Computers Ltd, a private company and Ciproco Computers, an unincorporated

40 ibid.

41 This point is eloquently made by Lord Macnaghten in Salomon v. Salomon \& Co. Ltd. [1897]' AC 22, 51:

The company is at law a different person altogether from the subscribers to the memorandum; and, though it may be that after incorporation the business is precisely the same as it was before, and the same persons are managers, and the same hands receive the profits, the company is not in law the agent of the subscribers or trustee for them. Nor are the subscribers as members liable, in any shape or form, except to the extent and in the manner provided by the Act.

42 The issue of unfairness may be exemplified by reference to the decision Sidebottom v Kershaw, Leese \& Co [1920] 1 Ch 154 (CA) .In that case, a private company in which majority of the shares were owned by the directrs, the articles of association was altered empowering directors to commpel any shareholder with a competing business to transfer his shares at their respective fair value to nominees of the directors. Sidebottom, a minority shareholder with a competing business, sued for a declaration invalidaiting the special resolution altering the memorandum of association. His claim failed as Lord Sterndale MR, at 165-166 explained the rationality of the alteration in the following words:

In my opinion, the whole of this case comes down to rather a narrow question of fact, which is this: When the directors of this company introduced this alteration giving power to buy up the shares of members who were in competing businesses did they do it bona fide for the benefit of the company or not? It seems to me quite clear that it may be very much to the benefit of the company to get rid of members who are in competing businesses. ... [L]ooking at it broadly, I cannot have any doubt that in a small private company like this the exclusion of members who are carrying on competing businesses may very well be of great benefit to the company. That seems to me to be precisely a point which ought to be decided by the voices of the business men who understand the business and understand the nature of competition, and whether such a position is or is not for the benefit of the company. I think, looking at the alteration broadly, that it is for the benefit of the company that they should not be obliged to have amongst them as members persons who are competing with them in business, and who may get knowledge from their membership which would enable them to compete better. 
partnership. ${ }^{43}$ It is quite probable that all that would have mattered to the average customers dealing with the Ciproco Computers is the words 'Ciproco Computers'. ${ }^{44}$

It would appear that in the present case, there was solid evidence of unfair conduct on the part of the respondents and also that they were obviously associated with the appellant company and it would seem that these factors have influenced the AD's ultimate finding in the case. ${ }^{45}$ Let us assume that in a future case, where some persons related to an unincorporated entity uses names similar to that of a company with which they have no formal or informal link, technically by doing this, they would not violate any provision of the Companies Act or the Partnership Act 1932. As apparently, the name search function of the RJSC would only be limited to the search of the identical or deceptively similar name of existing corporate entities, it is logical to deduce that it would be unable to identify any overlap at that stage. It is unknown how the Court would resolve such a case. ${ }^{46}$ Obviously, an action for passing off may be an option for proceeding against the unfair practice of the unincorporated business. ${ }^{47}$ The tort of passing off would afford a remedy against any deceptive invasion of a property interest in the goodwill of a business, which may injured by the misrepresentation on the part of another person that the latter's good or services are the goods or services of the first person. ${ }^{48}$

Suffice to say that passing off being a common law remedy, the Trade Marks Act $2009^{49}$ or other relevant statutory laws in force in Bangladesh does not mention the prerequisites for bringing an action for passing off. ${ }^{50}$ For instance, in Ewing $v$ Buttercup Margarine Co Ltd, the petitioner company which was carrying on business with the trade name of the Buttercup Dairy Company, was held by the English Court to be entitled to obtain an injunction for preventing a newly registered company from conducting business under the name of Buttercup Margarine Co, as the Court opined that the consumers could reasonably perceive that newly registered company was associated with the business of the petitioner ${ }^{51}$ However, the same restriction would not apply when the name is too descriptive or is used as a common word, as Aerators Ltd v Tollitt, the suit of a company named Aerators Ltd, against another company Automatic Aerators Patents Ltd, as the English Court held that 'Aerator' was a too

43 Md. Rizwanul Islam, 'Use of Similar Names by Companies' The Daily Star (Online, 23 December 2014) <http://www.thedailystar.net/use-of-similar-names-by-companies-56593> accessed 1 October 2020.

ibid.

ibid.

ibid.

ibid.

48 Gail Evans, 'Passing off' in Peter Cane and Joanne Conaghan (eds), The New Oxford Companion to Law (Oxford University Press, 2008) 874.

49 Act No. 19 of 2009

50 Md. Rizwanul Islam, 'Bangladesh' in Hendrik Vanhees (ed), International Encyclopedia of Laws: Intellectual Property (last updated version, Kluwer Law International 2020) 79.

51 [1917] 2 Ch 1. 
common word which could not be monopolized by a particular company ${ }^{52}$ However, when the descriptive name assumes a secondary name as distinct from the ordinary meaning of the word/s or the descriptive word is accompanied by various other features, it would be eligible for protection. ${ }^{53}$

Such a presumption of confusion may not operate when the business of the two parties are in totally unrelated areas. ${ }^{54}$ However, suffice to say that although passing off is an alternative remedy, in an action for passing off, the plaintiff business would be compelled to satisfy a higher threshold than that of a statutory action for infringement. This is because that it is relatively well-known that there are three preconditions for succeeding in an action of passing off, namely: (1) the petitioner must establish that its business enjoys sufficient goodwill (2) the defendant is liable for misrepresentation in the course of business to customers or potential customers about the relevant good/s or service/s which would likely deceive the latter that the defendant's good/s or service/s are actually that of the plaintiff's, and (3) the misrepresentation is actually occasioning loss actual loss to the plaintiff's business or would likely to do son. ${ }^{55}$ While the first and third elements may be provable by any business, the existence of goodwill may prove to be a thorny issue for most new businesses. Having said that, it is well-established that the registration of a company name, in and of itself, cannot give unqualified right to use that name and the company may still be answerable in action for passing off. ${ }^{56}$

Let us assume, a hypothetical scenario that the appellant and respondents in the Ciproco Computer Case were unrelated to each other. Let us further assume that Ciproco Computers started its business earlier and then Ciproco Computers Ltd was incorporated and both of these two entities have been concurrently in operation. Then Ciproco Computer as the prior in business sues Ciproco Computers Ltd for passing off. It is possible that if they are operating for the nearly same length of time, then both of the two may have some degree of goodwill. In this case of potentially concurrent use of similar name, instead of ordering an injunction in favour of one of the businesses, the Court may order the successor in time to use the name with a caveat that it uses This firm has no connection with the original firm Ciproco. Although the modification of name as envisaged in the case of a confusing name is an

[1902] 2 Ch 319.

Deputy Registrar, Trademarks, Chittagong v. M/S. Popular Polish House (1969) 21 DLR (SC) 114.

54 Dunlop Pneumatic Tyre Co Ltd v Dunlop Motor Co Ltd [1907] AC 430. But the presumption would not be dispelled when the goods are not identical but somewhat related, for example in Long's Hat Stores Corporation v. Long's Clothes, Inc., New York Supreme Court, Appellate Division, 231 N. Y. Supp. 107, Long's Hat Stores Corporation could obtain an injunction against Long's Clothes, Inc., reproduced in 'Corporation Entitled to Enjoin Use of Name Similar to Its Corporate Name' (1929) 13 Business Law Journal 298.

56 Wim Alberts, 'The Right to Use a Registered Trade Mark or Company Name' (2006) 14 Juta's Business Law 110, 112. 
alternative, if the second business has invested enough money in its marketing, this concurrent use with caveat could be an option.

Another option could have been to give the right to third parties to challenge the impending registration of a company on the ground the registration of a company under a proposed name would be undesirable. On a cursory reading Section 11(4) of the Companies Act 1994 it may appear that under the existing provision, there is a scope for this. However, indeed that Section only confers on the Government a right to declare by notification in the Public Gazette that no company would be registered in names which have been declared as undesirable. The objective of Section 11(4) is clearly that of the protection of public benefit. This is by no means a right conferred upon a private party. If third parties could challenge the proposed registration of a name or apply for its change on the ground that it impinges upon its reputation, that could afford an opportunity to any well-established unincorporated entities to challenge the registration of a company name. A model for this exists in Section 69 of the Companies Act 2006 of the United Kingdom. Section 69(1) states that a "person ... may object to a company's registered name on the ground that it is the same as a name associated with the applicant in which he has goodwill, or (b) that it is sufficiently similar to such a name that its use in the United Kingdom would be likely to mislead by suggesting a connection between the company and the applicant." Objections of this nature has to be presented to a Company Names Adjudicators who are appointed by the Secretary of State. ${ }^{57}$ The persons appointed need to possess legal or other experience which in the Secretary of State's opinion render them suitable for appointment. ${ }^{58}$

Clearly, the scope of this provision is much broader than the corresponding provision in Section 11 of the Companies Act 1994 as in force in Bangladesh, as the latter only applies to the similarity in name between two companies, but the former has no such limitation. If an objector to a name proposed for a company can prove either of the elements of Section 69(1), the company must prove that:

(a) that the name was registered before the commencement of the activities on which the applicant relies to show goodwill; or

(b) that the company-

(i) is operating under the name, or

(ii) is proposing to do so and has incurred substantial start-up costs in preparation, or

(iii) was formerly operating under the name and is now dormant; or 
(c) that the name was registered in the ordinary course of a company formation business and the company is available for sale to the applicant on the standard terms of that business; or

(d) that the name was adopted in good faith; or

(e) that the interests of the applicant are not adversely affected to any significant extent. ${ }^{59}$

The registration of a company name may also come in conflict with the owners of a prior registered trade mark owned either by a company or unincorporated entity. This is because there may also be the owners of a trade mark with whose trade mark, the name of a company is confusingly similar. Currently, the Companies Act 1994 does not contain any provision in this regard. However, the Indian Companies Act 2013 provides a provision which may serve as a model for the Companies Act 1994. Section 16(1)(b) of the Companies Act 2013 of India provides:

On an application by a registered proprietor of a trade mark that the name is identical with or too nearly resembles to a registered trade mark of such proprietor under the Trade Marks Act, 1999, made to the Central Government within three years of incorporation or registration or change of name of the company, whether under this Act or any previous company law, in the opinion of the Central Government, is identical with or too nearly resembles to an existing trade mark, it may direct the company to change its name and the company shall change its name or new name, as the case may be, within a period of three months from the issue of such direction, after adopting an ordinary resolution for the purpose. ${ }^{60}$

While such an unincorporated entity who is affected by the clash with its trade mark may always bring an action for passing off, the challenge to registration being an administrative remedy before the RJSC would seem to be much less costly and expeditious. It would be submitted that should the Parliament make any changes to the existing law giving the third parties an option to challenge the registration of a name, instead of creating a new class of persons such as the Company Names Adjudicator in the United Kingdom, the RSJC could be vested with this function.

\section{Conclusion}

As the economy of Bangladesh progresses, it is likely that the investment would increase and the number of both incorporated and unincorporated business would also increase. In a similar vein, the number of registered trademarks is also likely to increase in Bangladesh. Thus, it is possible that the confusing similarity between the names of a company and an unincorporated business or between a corporate name 
and registered trade mark would give rise contentious situations. The analysis of this article would clearly connote that neither Section 11 nor any other provision in the Companies Act would likely be applicable to resolve such a conflicting situation. It would be interesting to notice how in future the Supreme Court handles a situation in like what happened in Ciproco Computers. All that can be said is that a strictly literal reading by courts as was done by the HCD in the current case may help unscrupulous businesses to gain an unfair advantage over those businesses who might have gained popularity among consumers.

While an action for passing off may offer some remedies in many cases, due do the relatively stringent requirements of succeeding in an action for passing off; some businesses may not be able to succeed in an action for passing off. In other words, the parties who are relatively newcomers in the market may struggle to succeed in the alternative course of action of passing off. That being said, in practice, the very fact that the defendant has tried to pass off his goods as that of the plaintiff would in itself may be presumptuous to imply that the plaintiff has a goodwill in the relevant market. When both the plaintiff and the defendant would deal in identical goods, that presumption may be stronger, but when they would deal in unrelated goods or services, the presumption may be weaker. Thus, in the latter case, the evidentiary threshold of deception or likely confusion among consumers would be much higher. However, as can be gleaned from the decision of the HCD in Ciproco Computers that the outcome of an action in absence of an explicit statutory remedy is uncertain. Hence, it would be argued here that amendment to the Companies Act 1994 along the lines of Section 69 of the Companies Act 2006 of the United Kingdom and Section 16 Companies Act 2013 of India could offer a much more direct and predictable outcome. Not only that, but amendments of this nature could also be more affordable than a protracted court battle. 